\title{
Towards Sustainable Strategic Management: A Theoretical Review of the Evolution of Management Perception
}

\author{
Katarzyna Szymczyk ${ }^{1}$ \\ ${ }^{1}$ Czestochowa University of Technology, Poland \\ Correspondence: Katarzyna Szymczyk, Czestochowa University of Technology, Poland. E-mail: \\ katarzyna.szymczyk@wz.pcz.pl
}

Received: October 24, 2019

Accepted: November 15, 2019

Online Published: December 22, 2019

doi:10.5430/rwe.v10n4p58

URL: https://doi.org/10.5430/rwe.v10n4p58

\begin{abstract}
The article discusses issues related to the evolution of the concept of strategic management towards sustainable strategic management. In the literature, the idea of strategic management refers basically to the functioning of the organization and its activity in the economy. Currently, there is also an emphasis put on integrating environmental issues into the organization's activities and taking care of the interests of the society, so the strategic management should combine economic aspects with ecological and social care in mind of future generations. A change of an approach from strategic management to sustainable strategic management assumes implementation of management strategies that will protect natural resources, reduce the harmful activity of enterprises on the environment and take care of current and future populations. Just as the business environment and the perception of environmental interests change, so the strategic management itself does, as a concept itself and as a guideline for the business' functioning. Organizations following the idea of sustainable development, based on environmentally and socially friendly strategies, and aware of the consequences of their actions, here and now, are considered more productive and attractive, as well as stronger and more competitive. The evolution of general assumptions and approaches of strategic management changing within years towards the concept of sustainable strategic management enriched with the crucial environmental issues are discussed in this paper.
\end{abstract}

Keywords: strategic management, sustainability, sustainable business, management

\section{Introduction}

We are constantly experiencing changes in the behaviour of the organization, not only the direction of their actions or the choice of strategy changes but also the approach to the environment, on which organizations exert a continuous influence. The environment forces the business entities to change their approach to management because the previous management assumptions have brought benefits to the organization and their recipients, but also harm to the environment. Understanding how much attention must be paid to the needs of the environment is a breakthrough in the concept of strategic management. Now management should go towards sustainability, i.e. combining economic, social and environmental issues. Sustainable management means the necessity for organizations to be able to function freely and effectively and to make profits from their activities today and in the future. Over the decades, management has changed, and its key assumptions, strategies, and approaches to management have evolved along with the changing environment and its needs. Nowadays one can confidently admit it is the environment that has the greatest impact on how the business functions and what management strategies it should adopt so that its operation can bring tangible results, but without harming the surroundings. Such circumstances evoke the necessity for regarding management in the relationship with ecological and social sustainability. The new concept of sustainable management joins the strategic management, social responsibility, and sustainable development. The article presents the most important concepts of strategic management, which over the years have undergone constant transformations in the practical and theoretical sphere to develop the best possible range of strategies to improve the business' activities. The review of the literature allowed selection of the most important ideas and research results in the field of strategic management, which, along with the need of present times, has been focusing on including aspects of sustainable development into the organization management strategies.

\section{Method}

The presented paper covers a wide range of literature from an authoritative and critical perspective and provides a 
comprehensive overview of research on strategic management and its integration with the ecological and social sustainability. A choice of literature has been made with the use of backward and forward snowballing literature review method. The paper evaluates, classifies, and compares the principal notions of strategies of management developed over the decades, which has been nowadays changing towards the concept of sustainable strategic management.

\section{Discussion Based on a Literature Review}

\subsection{Strategic Management Approaches in Management Sciences}

Strategic management and the importance of strategy in other scientific and social fields, especially in the field of operational research, began to be discussed already in the 1950s. At that time, the theory of long-term planning (even more than five years) prevailed as a strategy of action based on the stages in a systematic and formal process. The key element was planning, programming, and goal setting, and the strategies were developed based on the strengths and weaknesses of the company, opportunities, and threats resulting from conditions (Obłój, 2007). According to R. Krupski (1999), the emergence of the concept of strategic planning occurred in the United States during the terrible events related to the oil crisis in the first half of the seventies of the last century. Then, the term strategic management started to be used. Yet, it has not been possible to introduce definitions of strategic management over the decades explicitly and the term is interpreted differently (Krupski, 1999). Referring to the observations of M. Lisiński (2004), J. Fudaliński (1995), A. Stabryła (1995), K. Michałowski (2008), J. Penc (2001), Z. Pierścionek (2003), J.R. Schermerhorn (2008), B. Nogalski (2004), M. Romanowska (1995), or E. Frąckiewicz et al. (2004), it is possible to boldly identify the essential attributes of strategic management, that in fact it is most often perceived as a process aimed at a specific goal, to achieve whose organization includes its own thinking, competences, decisions, actions and observations, as well as diagnoses of the environment and its own "I", which as a whole closes in the strategy undertaken by the organization (enterprise). For strategic management researchers, particular attributes will be more or less important, which in decades has allowed identifying some different approaches and strategic management schools and strategies themselves. Following this line of thinking, strategic management can be considered through the prism of approaches to classical overtones characterized by generality and formalism or more substantive exploring such features as position in the environment, relations and possibly emerging problems in relation to the environment and even taking up the fight with the environment (Krupski, 1999). The most commonly recognized as fundamental in strategic management are four approaches: planning-based approach, evolution-based approach, positioning and resource-based approach (Stonehouse et al., 2001; Otola, 2013). Each of the above approaches reflects the various concepts and insights of the subject researchers in the literature regarding the strategy, which strongly emphasizes the complex and continuing research character of the concept of strategic management. Therefore, strategies are captured, on the one hand, in the context of long-term plans and objectives based on their implementation programs. They are captured through the prism of not only plans and programs, but also actions and orientations to achieve the set goals through resources and their proper allocation to a given process, to appropriately plan the use of available resources in the near future. On the other hand, the strategy will refer to the relationship of the company with the environment through the appropriate combination of these two characters or concentration on changes in the environment and the company itself but also focusing attention on the decision process that is taken in the company or a set of decision-making techniques (Thomas, 1984; Ginsberg, 1988; Knights \& Morgan, 1991). Still, other researchers refer to the essence of building a competitive advantage and the company's performance or combine these concepts into an eclectic approach to strategy (Porter, 1996; Bowman et al., 2002; Nag et al., 2007).

\subsection{Evolution of Strategic Management and Organization Behavior}

The behavior of the organization and the companies constantly manifests itself in its activities, and it is present in a number of rules and principles or established patterns of conduct, whose nature and structure should enable the company to follow the environment, and if possible, overtake them, and perhaps actively build and organize this environment (Krupski, 1999). Strategic management has evolved along with changing views on strategies. A wave of harsh criticism of the strategic planning approach (synoptic approach) appeared when the new perception of strategic management in the incremental approach gave rise to the concept of creating conditions to implement the company vision in the long-term dimension in contrast to the implementation of the strategic planning. It was a kind of milestone that allowed the birth of strategic management concept and introduced fresh ideas for managing the company. Mission, analysis of the environment, strengths and weaknesses of the company, risk-taking, focus on staff training are just some of the attributes of strategic management as a concept from the 80s of the 20th century. The perception of the company, strategy, and management have changed. Old, still important paradigms replaced new ones, as well as the general perception of management and entrepreneurship as civilization signs of progress was 
introduced and the new thinking formulated new patterns (Nowicka-Skowron \& Stachowicz, 2009). Through bold and liberating management, the company has become to be able to choose the right strategic course (Urbanowska-Sojkin et al., 2007). Bearing in mind the above statements, one can consider the strategic management approach in a narrowing down to two opposite basic approaches: synoptic and incremental, and then analyze concerning assumptions taken from a positional and resource approach. Every company or organization in a broader sense will choose for themselves the most important and most useful attributes of approaches to develop individual strategies. There will also be enterprises that, like strategic thinking, have evolved along with the changing environment, and thus their strategies and views have also been subject to changes, to a greater or lesser extent. Therefore, the question arises, is there a universal approach for everyone? It is not possible to answer this question unambiguously. The first approach in line with the planning assumptions captured the strategy as the embodiment of specific decisions in action. The pattern was subject to change as the company functioned and also under the influence of behavioral initiatives in the field of management. This coherent whole of understanding strategy has torn down the incremental approach, which has inversely defined the concept of strategy as the resultant of targeted and emergent strategic actions, a strategy that does not result from organized organizational reality but from the process of learning and gaining experience, thanks to which this strategy arises incrementally, i.e., growing.

Along with the emergence of the concept of strategic position, the company was analyzed through the prism of its market position and the competitive advantage usually achieved by reducing costs and skillfully overcoming competitors. The observation of the business environment, assessment of the company's position and its competitive attributes was the key, which constituted the core of the positioning approach. This stage of strategic management development spawned further significant determinants of the company's success in achieving its own goals, namely the resource approach. The company should not only have many skills to achieve the market position but be able to use its assets, resources in various compilations to develop specific competencies and their use in building the company's strategy. Therefore, it should be understood that not only did the art of creating the organization's strategy change but the strategic thinking itself, which evolved along with the changing market needs (Brzozowska \& Szymczyk, 2017). The transition from financial planning to focusing on people and knowledge and strategic management was certainly a decisive phase in the development of strategic thinking, which gave rise to the perception of the organization in the context of its environment, both closer and further.

\subsection{Towards Sustainability in Management}

At present, the challenge for enterprises is to meet the requirements of the global market and global trends. Recalling R. Krupski's (1999) considerations, both company policy and strategic management require a focus on "adding value and value relevant to the client". That also means changes in the structure of the company itself, in systems and identification of goals that should include the increase of productivity, company's efficiency, optimization of the flow of goods, improvement of the work's contribution, vision and mission of the enterprise and its positioning. These elements constituted the core of the process approach in management, which was initially born from the concept of Business Processing Reengineering, but nowadays functions as a Business Process Management (Bitkowska, 2009). Similarly, at the end of the 1980s, the Knowledge Management concept was created, and knowledge as a company resource is now another important factor in achieving the competitive advantage of the enterprise (Międła, 2010). However, there appeared the focus on the company's environment - the concept of the environment resulted from a systematic approach based on systems theory and cybernetics according to the concept of L. von Bertalantffy (1969) - where the company creates a system with related subsystems and elements interacting with each other. The functioning of an enterprise and its development in the systemic approach can be described as dependence on specific developmental proportions between particular subsystems, as well as dependencies on those proportions occurring within each subsystem. To describe these relationships, one must also add relations with the environment, which is a larger system, whose enterprise is a component (Otola, 2005; Otola, 2013; Lichtarski, 2001). But the company's environment is also a natural ecosystem that the company constantly influences through its activities. This ecosystem is a platform for action, interaction, and cooperation between society, policymakers, institutions, the private sector, and the environment. It is the moment when the strategic management should go towards sustainable strategic management that combines its economic interests with the interests of society and the caring for the natural environment. Therefore, if the essence of strategic management so far has created the value-added and the value for the client, the modern strategic management should also be sustainable, i.e., focused on creating the value for clients, the environment and society based on long-term business solutions. Consequently, the strategies undertaken by the organization should become sustainable strategies that bear in mind all possible conventions for current and future generations (Stead \& Stead, 2013). This means creating a new hierarchy of values and organizational behaviour patterns, so that present and future generations can co-exist in harmony with nature, i.e. limiting and controlling 
excessive consumption, preventing the extensive destruction of natural resources in the name of mass production and generating profits, inappropriate and harmful waste management (Darban Astane \& Hajilo, 2017; Skawińska et al., 2010; Rubaszkiewicz, 2008; Paliwoda-Matiolańska, 2008; Kates et al., 2005; Goosen, 2012; Starik \& Kanashiro, 2013; Gwada et al., 2019). Enterprises must change the way of thinking and approach to management so that all developed strategies should go towards sustainable development and have in mind not their profits and willingness to generate revenues, but above all, the good of the environment and society as a foundation for the future of the organization. The times of excessive consumption, unlimited production with an attitude we produce a lot and cheap should be far behind us, and what is now the most important is conscious production without negative consequences for the natural environment and making investments in renewable resources, which maintain as money or savings in bank for future generations (Andersen, 2007; Stead \& Stead, 2013). Each organization must change the policy towards sustainability and implement only strategies that would transform the business environment, and so a current need for consumption decreases and the awareness of how goods impact the environment grows. The sustainable strategic management focused on business functioning preserving the natural resources is unavoidable. The organizations which include the so-called green (ecological) policy (i.e. regarding the changes (warming) of the climate, fighting with the exceeded emission of carbon dioxide, overexploitation, habitat degradation, pollution of water and land) will stay on the market. Such entities will be regarded as beneficial, i.e. in other words, only those who reconcile the interests of the environment with their economic goals will count on the markets and manage to maintain a competitive advantage (Klarin, 2018; Isopescu, 2018; Karamidehkordi, 2012; Tàbara \& Pahl-Wostl, 2007). Thinking about sustainability, the organization should follow the concept of a circular economy rather than a linear economy. In linear creativities for sustainable development, recycled products are not re-used due to the lack of entities ready to treat them as raw materials for new production, thus there exist the missing value chains. Unfortunately, currently, production processes to a large extent favor the use of primary readily available resources, and this should be permanently changed. Changing an approach to production system should be regarded as a mission of the organization, i.e., it should concern all consequences of introducing the product to the market whether the product satisfies the client and how it influences the environment, as well. Thus, the answer to uncertainties can be a changing the linear approach to the circular economy model, which is clearly resource-oriented, because the circular economy seeks to include all inputs and results of the production process and puts a lot of pressure on waste. Such a model is more likely to bring better results towards sustainable development, so it can be assumed that the implementation of a circular economy promotes sustainable development. The circular economy is principally linked to eco-design and a life-cycle analysis that essentially forms its foundation. Eco-design-based organizations must consider whether each stage of the product life cycle is safe for the environment. Environmental reasons should be integrated with the design and development of the product at every stage of its life, some stages that take into account environmental aspects cannot simultaneously cause environmental damage in subsequent stages of the product life, for example too complicated recycling or re-use after its life. Therefore, forcing the organizations to adopt the model of the circular economy may bring a profound sustainable approach in their management strategies based on the life cycle of products which includes the sustainability in all product life phases (Sauvé et al., 2016). Strategic thinking must go together with sustainability at each step of production and functioning of the organization in a business environment. The way the organization presents itself on the market defines its position, competitive advantage and market role. Sustainable businesses have become to be regarded as respectful, more effective and attractive, and perceived as strong and dynamic market players. In near future, such player, who has a strong and well-thought-out strategy of action, oriented towards the benefits of the recipients, the environment and finally the own good, will conquest the market. The policy of the organization focused on the pro-environmental function, protection of nature and the weakest, decisively will win with the politics of profit-oriented organizations at the lowest costs and the approach excluding environmental needs (Witek-Crabb, 2012; Stead \& Stead, 2013). What are then the sustainable strategies for organizations (enterprises)? Undoubtedly, there are some crucial ones such as:

— implementing energy and natural resources saving production,

- reuse of materials,

- limiting the mass production of products not able to be absorbed by the market,

- complete management of waste,

- ecological packaging,

- carbon dioxide emission reducing transport,

— smart and optimized freight delivery, 
- outsourcing limiting exploitation and illegal employment,

- implementation of innovations supporting sustainable production and trade,

and other similar good practices in business reducing the human footprint and refining the value of human life.

\section{Conclusions}

Each organization (enterprise) focuses mostly on its economic profits. So far, many discussions on the functioning of the organization in the economy have been devoted mainly to issues related to strategies for winning markets and customers, optimizing production costs, competitiveness or organizational development trends in a turbulent, highly competitive environment, full of unpredictable changes. Today, business strategies need to be not only economically competitive but should also be socially and environmentally responsible. Therefore, the old and standard concepts of strategic management need to be changed into sustainable strategic management, which involves implementing only those strategies of business that stay in balance with the cycles of nature. The ecological protection and focus on social aspects have become a vital issue of modern management. The organizations' task nowadays is acquiring adequate knowledge of new ways of formulating strategies of management that are beneficial from the economic point of view and sustainable at the same time. The sustainable strategic management should become a profound approach of any business in current realities if this business wants to stay competitive on the market, gain the consumers' attention and play a significant role among other market actors. The evolution and evaluation of goals and strategies of the organizations towards sustainability emerged from the needs of the natural eco-system and should be regarded as the obligatory new way of thinking if one considers running the business today and in the future with the respect of societies and the natural environment.

\section{References}

Andersen, M. S. (2007). An introductory note on the environmental economics of the circular economy. Sustainability Science, 2(1), 133-140. https://doi.org/10.1007/s11625-006-0013-6

Bertalanffy, L. von. (1969). General System Theory. New York: George Braziller.

Bitkowska, A. (2009). Zarządzanie procesami biznesowymi w przedsiębiorstwie. Warszawa: VIZJA.

Bowman, E. H., Singh, H., \& Thomas, H. (2002). The domain of strategic management: history and evolution In A. Pettigrew, H. Thomas, \& R. Whittington (Eds.), Handbook of Strategy and Management (pp. 31-51). London: Sage.

Brzozowska, A., \& Szymczyk, K. (2017). Management Through Opportunities as an Unconventional Solution in the Theory of Strategic Management. In I.M.M. El Emary, \& A. Brzozowska (Eds.), Shaping the Future of ICT. Trends in Information Technology, Communications Engineering, and Management (pp. 377-387). Boca Raton: CRC Press Taylor \& Francis Group.

Darban Astane, A. R., \& Hajilo, M. (2017). Factors affecting the rural domestic waste generation. Global Journal of Environmental Science and Management, 3(4), 417-426. https://doi.org/10.22034/gjesm.2017.03.04.007

Frąckiewicz, E., Karwowski, J., Kwiatkowski, M., \& Rudawska, E. (2004). Zarzadzanie marketingowe. Warszawa: PWE.

Fudaliński, J. (2002). Analizy sektorowe w strategicznym zarządzaniu przedsiębiorstwem. Kraków: Antykwa.

Ginsberg, A. (1988). Measuring and modelling changes in strategy: theoretical foundations and empirical directions. Strategic Management Journal, 9(6), 559-575. https://doi.org/10.1002/smj.4250090604

Goosen, M. F. A. (2012). Environmental management and sustainable development. Procedia Engineering, 33 , 6-13. https://doi.org/10.1016/j.proeng.2012.01.1171

Gwada, B., Ogendi, G., Makindi, S. M., \& Trott, S. (2019). Composition of plastic waste discarded by households and its management approaches. Global Journal of Environmental Science and Management, 5(1), 83-94. https://doi.org/10.22034/gjesm.2019.01.07

Isopescu, D. N. (2018). The impact of green building principles in the sustainable development of the built environment. IOP Publishing Conf. Series: Materials Science and Engineering, 399, 1-9. Retrieved from https://iopscience.iop.org/article/10.1088/1757-899X/399/1/012026/pdf

Karamidehkordi, E. (2012). Sustainable Natural Resource Management, a Global Challenge of This Century. In A. Kaswamila (Ed.), Sustainable Natural Resources Management (pp. 105-114). London UK: IntechOpen.

Kates, R. W., Parris, T. M., \& Leiserowitz, A. A. (2005). What Is Sustainable Development? Goals, Indicators, 
Values, And Practice. Environment: Science and Policy for Sustainable Development, 47(3), 8-21. Retrieved from https://sites.hks.harvard.edu/sustsci/ists/docs/whatisSD_env_kates_0504.pdf

Klarin, T. (2018). The Concept of Sustainable Development: From Its Beginning to the Contemporary Issues. Zagreb International Review of Economics \& Business, 21(1), 67-94. https://doi.org/10.2478/zireb-2018-0005

Knights, D., \& Morgan, G. (1991). Corporate strategy, organizations, and subjectivity: a critique. Organization Studies, 12(2), 251-273. https://doi.org/10.1177/017084069101200205

Krupski, R. (1999). Zarzadzanie strategiczne. Koncepcje, metody. Wrocław: Wydawnictwo Akademii Ekonomicznej we Wrocławiu.

Lichtarski, J. (2001). Podstawy nauki o przedsiębiorstwie. Wrocław: Wydawnictwo Akademii Ekonomicznej we Wrocławiu.

Lisiński, M. (2004). Metody planowania strategicznego. Warszawa: PWE.

Michałowski, K. (2008). Podstawy zarządzania turystyka. Aspekt przestrzenny. Białystok: Wydawnictwo Wyższej Szkoły Ekonomicznej w Białymstoku.

Międła, K. (2010). Podejście procesowe a zarządzanie wiedzą. Prace Naukowe Uniwersytetu Ekonomicznego we Wrocławiu. Nauki o Zarzadzaniu, 4(137), 55-63.

Nag, R., Hambrick, D. C., \& Chen, M. J. (2007). What is strategic management, really? Inductive derivation of a consensus definition on the field. Strategic Management Journal, 28(9), 935-955. https://doi.org/10.1002/smj.615

Nogalski, B. (2004). Zarzadzanie antykryzysowe przedsiębiorstwem. Pokonać kryzys $i$ wygrać. Warszawa: Difin.

Nowicka-Skowron, M., \& Stachowicz, J. K. (2009). Innowacyjność zarządzania w organizacjach przemysłowych, publicznych i regionach wyzwaniem dla nauk o zarządzaniu. In M. Nowicka-Skowron (Ed.), Zarzadzanie sieciami wspóldziałania $w$ procesie budowy innowacyjnej organizacji i regionu (pp. 59-67). Czestochowa: Wydawnictwo Wydziału Zarządzania Politechniki Czestochowskiej.

Obłój, K. (2007). Strategia organizacji. Warszawa: PWE.

Otola, I. (2005). Istota synergii w kontekście systemowego podejścia do organizacji. In L. Sobolak (Ed.), Kierunki $i$ metody zarzadzania organizacjami w zintegrowanej Europie (pp. 66-70). Czestochowa: Wydawnictwo Wydziału Zarządzania Politechniki Czestochowskiej.

Otola, I. (2013). Procesy zarzadzania przedsiębiorstwami a konkurencyjność w warunkach zarażonego rynku. Czestochowa: Wydawnictwo Wydziału Zarządzania Politechniki Czestochowskiej.

Paliwoda-Matiolańska, A. (2009). Odpowiedzialność społeczna w procesie zarządzania przedsiębiorstwem. Warszawa: Wydawnictwo C.H. Beck.

Penc, J. (2001). Strategiczny system zarzadzania. Warszawa: Agencja Wydawnicza PLACET.

Pierścionek, Z. (2003). Strategie konkurencji i rozwoju przedsiębiorstwa. Warszawa: PWN.

Porter, M. E. (1996). What is strategy? Harvard Business Review, 74(6), 61-78. Retrieved from http://www.instituteofbusinessstrategy.com/strategy.pdf

Romanowska, M. (1995). Zarządzanie strategiczne firma. Warszawa: Centrum Informacji Menedżera.

Rubaszkiewicz, J. (2008). Ochrona środowiska $w$ wymiarze międzynarodowym $i$ krajowym. Warszawa: Wydawnictwo Wyższej Szkoły Cła i Logistyki.

Sauvé, S., Bernard, S., \& Sloan, P. (2016). Environmental sciences, sustainable development and circular economy: Alternative concepts for trans-disciplinary research. Environmental Development, 17, 48-56. https://doi.org/10.1016/j.envdev.2015.09.002

Schermerhorn, J. R. (2008). Zarzadzanie. Kluczowe koncepcje. Warszawa: PWE.

Skawińska, E., Sobiech-Grabka, K. G., \& Nawrot, K. A. (2010). Makroekonomia. Teoretyczne i praktyczne aspekty gospodarki rynkowej. Warszawa: PWE.

Stabryła, A. (1995). Podstawy zarzadzania firma. Warszawa: PWN.

Starik, M., \& Kanashiro, P. (2013). Toward a Theory of Sustainability Management: Uncovering and Integrating the Nearly Obvious. Organization \& Environment, 26(1), 7-30. https://doi.org/10.1177/1086026612474958 
Stead, J. G., \& Stead, W. E. (2013). The Coevolution of Sustainable Strategic Management in the Global Marketplace. Organization \& Environment, 26(2), 162-183. https://doi.org/10.1177/1086026613489138

Stonehouse, G., Hamill, J., Campbell, D., \& Purdie, T. (2001). Globalizacja. Strategia i zarzadzanie. Warszawa: FELBERG SJA.

Tàbara, J. D., \& Pahl-Wostl, C. (2007). Sustainability learning in natural resource use and management. Ecology and Society, 12(2). Retrieved from http://www.ecologyandsociety.org/vol12/iss2/art3/

Thomas, H. (1984). Strategic decision analysis: applied decision analysis and its role in the strategic management process. Strategic Management Journal, 5(2), 139-156. https://doi.org/10.1002/smj.4250050205

Urbanowska-Sojkin, E., Banaszyk, P., \& Witczak, H. (2007). Zarzadzanie strategiczne przedsiębiorstwem. Warszawa: PWE.

Witek-Crabb, A. (2012). Sustainable strategic management and market effectiveness of enterprises. Procedia - Social and Behavioral Sciences, 58, 899-905. https://doi.org/10.1016/j.sbspro.2012.09.1068 